\title{
Partitioning of sediment on the shelf offshore of the Columbia River littoral cell
}

\author{
David C. Twichell ${ }^{\text {a,* }}$, VeeAnn A. Cross ${ }^{\text {a }}$, Curt D. Peterson ${ }^{b}$ \\ a US Geological Survey, Woods Hole, MA, United States \\ b Department of Geology, Portland State University, Portland, OR, United States
}

\section{A R T I C L E I N F O}

\section{Article history:}

Accepted 18 January 2010

Available online 11 February 2010

\section{Keywords:}

continental shelf

holocene sediments

Columbia River

\begin{abstract}
A B S T R A C T
Sediment derived from the Columbia River has been deposited on the continental shelf, along the barriers and beaches, and in the bays of the Oregon and Washington coast during the Holocene. The barrier and beach deposits of this $150-\mathrm{km}$ section of coast comprise approximately $6 \mathrm{~km}^{3}$ of these Holocene sediments (Peterson et al., 2010-this issue) while the fluvial and bay deposits comprise about $104 \mathrm{~km}^{3}$ (Baker et al., 2010-this issue), and the shelf deposit is approximately $79 \mathrm{~km}^{3}$. Seismic-reflection, sidescan sonar, and surface sediment data show that the shelf deposit is not uniform in distribution or composition. The shelf deposit is $15-50 \mathrm{~m}$ thick off the beaches of the southern part of the study area but is less than $3 \mathrm{~m}$ thick, and, in places, absent from the inner shelf in the northern third of the study area. Surface sediment texture of the shelf deposit varies as well. Pleistocene-age gravel covers parts of the inner shelf in the northern third of the area. To the south, the surface of the Holocene shelf deposit is composed of fine sand near shore that grades offshore to dominantly very fine sand in $25-30 \mathrm{~m}$ water depth and muddy sand on the middle and outer shelf ( $>50 \mathrm{~m}$ depth). Although a huge volume of sediment covers the shelf, its uneven distribution indicates that in places only small amounts are available as a potential offshore source to the adjacent beaches, and in other places the finer-grained nature of the shelf deposit indicates that significant winnowing of fine sediment would be necessary to make it compositionally equivalent to sediment on adjacent beaches.
\end{abstract}

Published by Elsevier B.V.

\section{Introduction}

Many continental shelves are relict surfaces that have been partially reworked by coastal processes as the shoreface transgressed across the shelf during the Holocene (Curray, 1965; Emery, 1968). Understanding sediment exchange between the shelf and adjacent beaches has been difficult because of uncertainty in determining the degree to which shelf deposition results from modern marine processes or antecedent sediments that have been partially reworked (Swift, 1970; Schwab et al., 1997). The Columbia River littoral cell (CRLC) is one of the few sections of the US coast that is bounded offshore by a shelf that has accumulated a huge volume of sediment during the Holocene sea level rise (Nittrouer, 1978). The mineralogy of the beach sediment (Ballard, 1964) and shelf sediment (Gross et al., 1967) shows that the Columbia River has been the primary sediment source for both, and for this reason, this littoral cell provides an opportunity to study the linkage between a modern shelf and the adjacent accreting beach system. An integrated mapping of the surface and subsurface geology of this inner shelf area had not been available prior to this study. Here we summarize the stratigraphy and surficial geology of the continental shelf part of the CRLC using high-

\footnotetext{
* Corresponding author. U.S. Geological Survey, 384 Woods Hole Road, Woods Hole, MA 02543, USA. Tel.: +1 508457 2266; fax: +1 5084572310.

E-mail address: dtwichell@usgs.gov (D.C. Twichell).
}

resolution seismic-reflection profiles, sidescan sonar imagery, surface sediment samples, and bottom photographs.

\subsection{Background}

The continental shelf off northern Oregon and southern Washington is narrow, with a width of $20-30 \mathrm{~km}$ (Fig. 1). The surface is smooth, although incised along the seaward edge with five submarine canyons. Astoria Canyon is the largest of these canyons and indents the shelf about $20 \mathrm{~km}$ (Fig. 1).

Interpretation of seismic-reflection data shows that the smooth nature of the shelf surface is partially the result of the thick deposit of Holocene sediment, which covers irregularities in the pre-transgressive substrate (Nittrouer, 1978; Wolf et al., 1997; Twichell and Cross, 2001). This deposit extends northwestward diagonally across the shelf from the mouth of the Columbia River to Quinault Canyon. Seismic profiles on the middle and outer shelf show that it is as much as $50 \mathrm{~m}$ thick off the Columbia River, and thins to $15 \mathrm{~m}$ near Quinault Canyon (Nittrouer, 1978; Wolf et al., 1997). Short cores suggest that the mid-shelf mud accumulated at rates of 1-2 m/1000 yr (Nittrouer, 1978); whereas vibracores from the inner shelf suggest that recently sedimentation rates have decreased to only $20-30 \mathrm{~cm} / 1000 \mathrm{yr}$ (Kaminsky and Ferland, 2003). Previous geological surveys had focused on the middle and outer shelf. Consequently the shoreward extent and stratigraphy of the inner shelf part of the deposit was poorly defined due to a lack of data. 


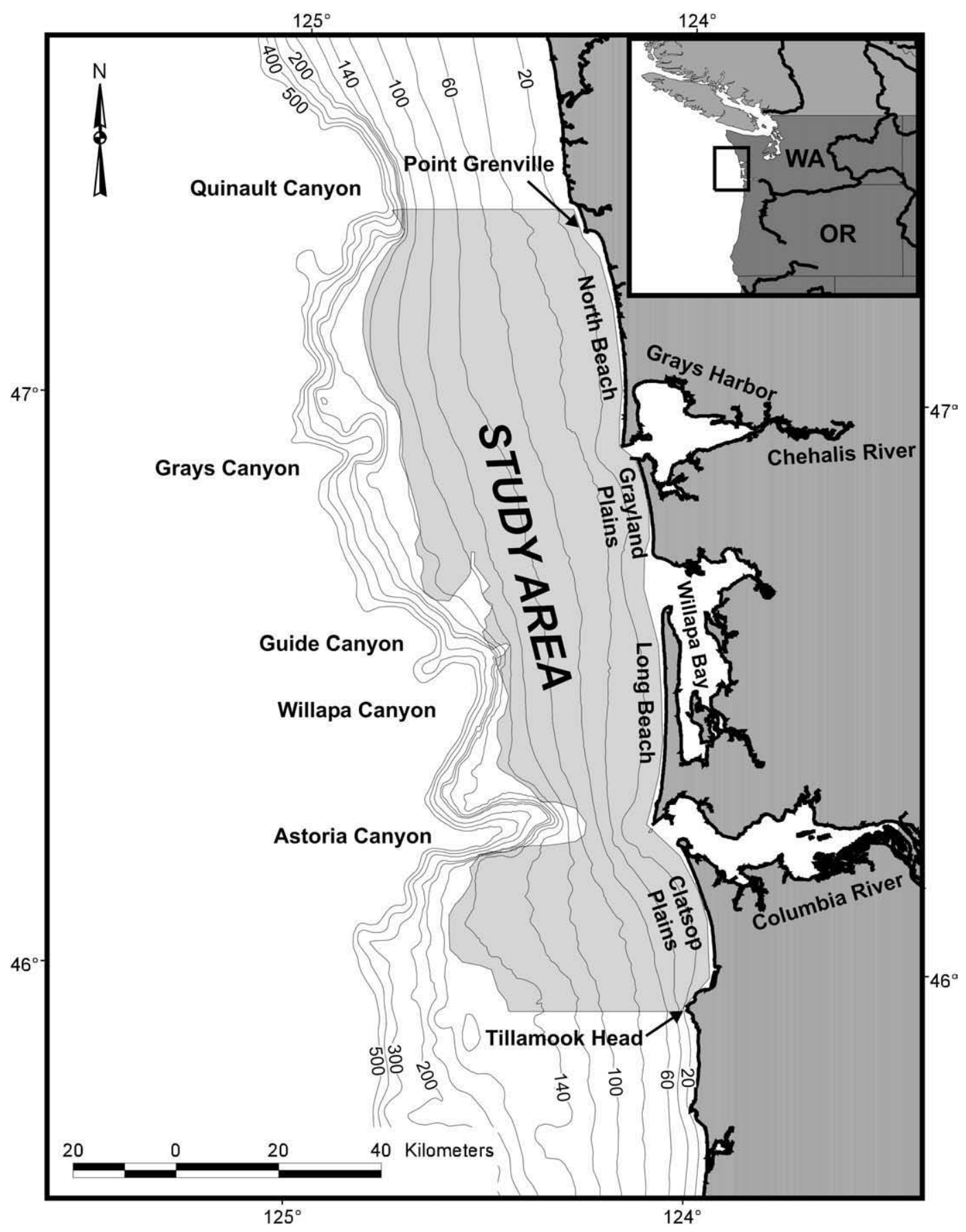

Fig. 1. Location of the study area off the northern Oregon and southern Washington coast. Bathymetric contours are in meters.

Surface sediment samples have been used to map the extent of the mid-shelf deposit (Nittrouer, 1978; Sternberg, 1986) and to identify the geology of the surrounding shelf surface. Patches of gravel of glacial origin occur along the shelf edge (Gross et al., 1967) and also on the inner shelf north of Grays Harbor (Venkatarathnam and McManus, 1973). The mid-shelf deposit is nearly an equal mix of sand and silt off the mouth of the Columbia River. The sand content decreases northwestward becoming almost absent in samples near Quinault Canyon (Nittrouer, 1978; Sternberg, 1986). The mid-shelf deposit becomes sandier towards shore. The inner shelf sediment is fine sand off Clatsop Plains and north of Grays Harbor and very fine sand from the mouth of the Columbia River north to Grays Harbor (Nittrouer, 1978; Sternberg, 1986).

Modern sediment movement on this shelf presumably is similar to sediment movement on the northern California shelf off the Eel River or on the neighboring Oregon shelf. Instrumentation on the Eel River shelf recorded active remobilization of sediment in $60 \mathrm{~m}$ of water associated with periods of significant wave activity, tidal currents, and river discharge (Ogston and Sternberg, 1999, Cacchione et al., 1999). The presence of ripples in water as deep as $200 \mathrm{~m}$ on the Oregon shelf indicates continued reworking of this shelf surface by winter storms (Komar et al., 1972). On the Washington shelf, maximum significant wave heights reach $8 \mathrm{~m}$ at a buoy near Grays Harbor moored in $40 \mathrm{~m}$ water depth (Gelfenbaum et al., 2003). Tides, which have a range of $2-4 \mathrm{~m}$, generate currents that are around $10 \mathrm{~cm} / \mathrm{s}$ on the middle shelf, but stronger at inlet entrances (Sternberg, 1986). Further support for dynamic movement of sediment on this shelf comes from historical bathymetric surveys, which show changes in seabed elevation between the 1920s and the 1990s that exceed $4 \mathrm{~m}$ near estuary 
mouths, and reach $2 \mathrm{~m}$ in localized areas of the inner shelf removed from inlets (Buijsman et al., 2003).

\section{Methods}

High-resolution seismic-reflection profiles, sidescan sonar imagery, sediment samples and bottom photographs were collected from the shelf part of the Columbia River littoral cell during 1997 and 1998 (Cross et al., 1999a,b; Twichell et al., 2000). Single-channel seismicreflection profiles and sidescan sonar imagery were collected from the inner and middle shelf along lines spaced approximately $5 \mathrm{~km}$ apart (Fig. 2). A Geopulse boomer or sparker was the sound source and an ITI or Benthos hydrophone was the receiver for the seismic-reflection data. A detailed summary of the seismic systems and the digital data processing are given in Cross et al. (1999a,b) and Twichell and Cross (2001). Sidescan sonar imagery was collected simultaneously along most of the seismic lines using an EdgeTech DF-1000 sidescan sonar system. These data were logged with a Triton Elics Isis data logging system. Twichell et al. (2000) provide a detailed summary of the sidescan processing procedures.

Sediment samples were recovered from 95 locations shown in Fig. 2. Samples were collected with a VanVeen grab sampler in a frame, which also held a video camera and 35-mm Benthos still camera (Blackwood and Parolski, 2001). Bottom photographs and video were acquired at most sample stations. Differential GPS or PCode GPS receivers were used for navigation of the seismic and sidescan sonar data and to locate sample sites, providing location precision to approximately $10 \mathrm{~m}$.

In the laboratory, samples were washed to remove the salt and then were sieved using a $62.5-\mu \mathrm{m}$ sieve to separate the silt and clay fraction from the sand and gravel fraction. The silt and clay fractions were analyzed by Coulter counter (Shideler, 1976). The sand and gravel fractions were sieved at $1 / 4$ phi intervals, and the results were recorded as percentages by weight. Size classifications are based on the method and nomenclature proposed by Wentworth (1929) and Krumbein (1934). Laboratory procedures have been described in detail by Poppe et al. (1985).

Sediment samples collected by Roberts (1974), Nittrouer (1978), and Smith et al. (1980) compliment the samples collected during this study (Fig. 2). These samples were not processed the same way as in this study, and comparison of these historical results with our results could only be done as percentages of gravel, sand, and silt plus clay.

\section{Results}

Three stratigraphic units are differentiated on the seismic profiles (Figs. 3, 4), and the surficial geology shows the distribution of exposures of each of these units on the present shelf surface (Fig. 5). The oldest unit is undifferentiated Tertiary-age strata, which include Eocene-age volcanic rocks offshore of Tillamook Head (Walker and McLeod, 1991), Tertiary marine sediments that underlie much of the study area (Twichell et al., 2000; McCrory et al., 2002), and localized intrusive features off Grayland Plains and North Beach (Figs. 3B, 4B). The Tertiary strata are commonly folded, and the unconformity that separates these strata from the overlying Holocene deposit is clearly identified on the seismic profiles (Fig. 3). Broad exposures of folded Tertiary strata are present on the inner and middle shelf north of Grays Harbor, and this part of the shelf is virtually free of Holoceneage sediment (Fig. 3A).

The second unit is gravel, which is exposed in patches on the inner shelf north of Willapa Bay (Figs. 4A, 5, 6) and discontinuously along the shelf edge (Venkatarathnam and McManus, 1973). The gravel is well rounded (Fig. 6A), has a provenance from the Olympic Mountains, and is interpreted to be Pleistocene-age glacio-fluvial deposits (Gross et al., 1967; Venkatarathnam and McManus, 1973). The sidescan imagery shows that the gravel is exposed on the sea floor in discontinuous patches off Grayland Plains and the North Beach areas (Figs. 4, 6). Some of the gravel patches are irregular in shape while others are extended in an E-W orientation (Fig. 6A). Many of them are surrounded by fine sand, have abrupt edges, and occupy the floors of shallow depressions. Multibeam bathymetry shows that these depressions have about $1 \mathrm{~m}$ relief (Flood et al., 1999). These patches are most common off the Grayland Plains. Grain size analyses show that the gravel is mostly 2$\mathrm{mm}$ to $2-\mathrm{cm}$ in diameter (Twichell et al., 2000).

An unconformity separates Holocene deposits from Tertiary and Pleistocene strata (Fig. 3). This unconformity has been drilled on land (Baker et al., 2010-this issue; Vanderburgh et al., 2010-this issue, Peterson et al., 2010-this issue), and radiocarbon dates indicate that it was cut, or at least was most recently modified, during and since the last sea level lowstand. This lowstand unconformity shows two welldeveloped valleys extending offshore from the Columbia River and Grays Harbor (Figs. 6B, 7A, 8C). The paleo-Columbia River valley extends to the head of Astoria Canyon. The smaller Chehalis River valley, due to limited seismic coverage, can only be traced from the mouth of Grays Harbor to the middle shelf. No valley is present off Willapa Bay either because the valley was so small it was not preserved or because it drained northward into the Chehalis River system shoreward of the shelf survey lines. The lowstand unconformity away from the two valleys is overprinted by a younger unconformity. This surface has a smooth seaward gradient under the shelf, but shows a shallow embayment underlying the present middle shelf south of the mouth to Willapa Bay (Fig. 7A).

The deposit overlying this lowstand unconformity is Holocene in age. Seismic profiles and wells (Peterson and Phipps, 1992; Baker et al., 2010-this issue) show that it can be broken into two units: (1) fluvial and bay deposits that fill paleo-river valleys and (2) an overlying shelf deposit with a much broader aerial extent (Fig. 7C). The sandy nature of these deposits probably explains why the fill is acoustically featureless on most of the seismic profiles (Figs. 6B, 8C). The fluvial and bay deposits exceed $50 \mathrm{~m}$ in thickness under the inner shelf in the paleo-Columbia River valley and $40 \mathrm{~m}$ in the paleoChehalis River valley. The total volume of fluvial and bay sediment in Willapa Bay and Grays Harbor and their offshore extensions is approximately $25 \mathrm{~km}^{3}$ (Peterson and Phipps, 1992; Twichell and Cross, 2001). The volume of Holocene sediment contained in the Columbia River basin exceeds $79 \mathrm{~km}^{3}$ (Baker et al., 2010-this issue), and because of the narrow shelf, only $6 \mathrm{~km}^{3}$ of this deposit lies offshore of the present shoreline. The total volume of fluvial and bay sediment is approximately $104 \mathrm{~km}^{3}$.

The second Holocene unit, the shelf deposit, overlies the fluvial and bay deposits. The two units are separated by an unconformity that was cut during the Holocene marine transgression (Fig. 7B). The marine transgressive unconformity and the lowstand unconformity are separate surfaces only in the paleo-river valleys, while on the interfluves the two unconformities merge (Fig. 8C). The flatness of the marine transgressive unconformity where it cuts the fluvial and bay deposits indicates that these valleys were filled with sediment before the shoreface crossed them (Figs. 7B, 8C). The shelf deposit is of greater lateral extent than the fluvial and bay deposits. Where it is not underlain by fluvial and bay deposits it overlies Pleistocene or Tertiary strata (Figs. 3, 4).

The Holocene shelf deposit is as much as $50 \mathrm{~m}$ thick on the middle shelf off the mouth of the Columbia River, and has a thick axis that trends northwestward diagonally across the middle and outer shelf (Fig. 7C). This deposit pinches out along its offshore side near the shelf edge. Its southern limit is somewhat south of Tillamook Head, while it extends northward past the limit of the study area to Quinault Canyon (Nittrouer, 1978; Sternberg, 1986; Wolf et al., 1997). On the innermost shelf the sediment above the marine transgressive unconformity is 20-30 m thick off Clatsop Plains and Long Beach (Fig. 3C, E). This deposit thins abruptly north of the mouth of Willapa Bay, where the underlying Tertiary strata shoal abruptly to within 2- 


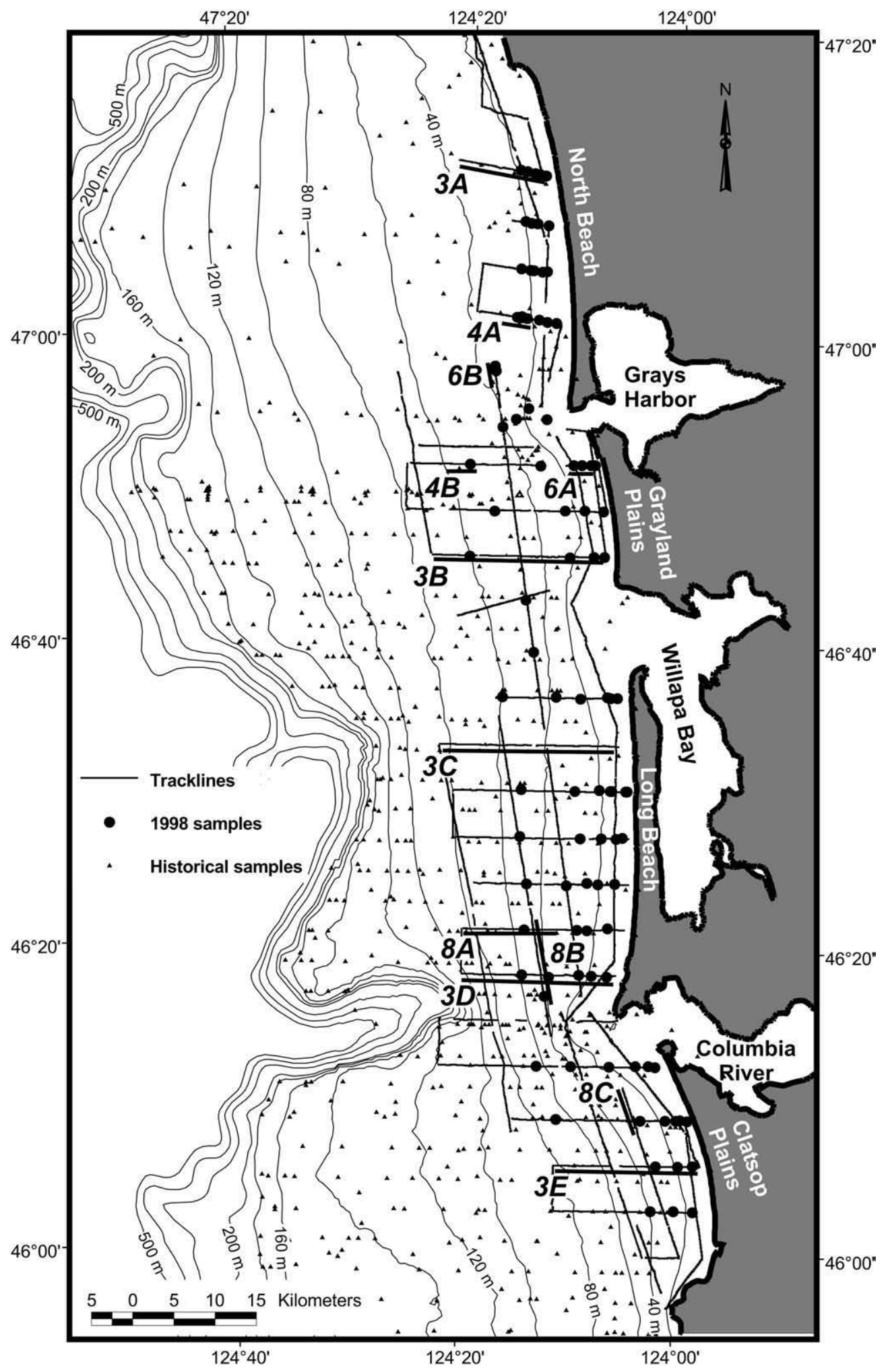

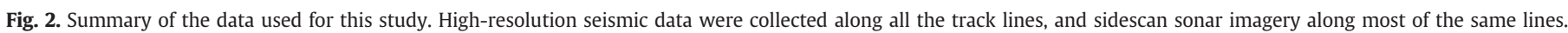

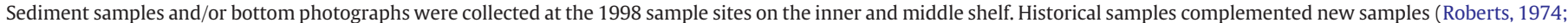
Nittrouer, 1978; Smith et al., 1980). Heavy, numbered line segments show locations of other figures. Bathymetric contours are in meters.

$5 \mathrm{~m}$ of the seafloor (Figs. 3B, 7C). North of Grays Harbor this deposit is absent except on the very innermost part of the shelf (Fig. 3A). This area, as was first inferred by Gross et al. (1967) based on sediment samples, is a relict shelf surface. Drill holes on the barriers shoreward of many of the seismic profiles penetrated barrier and shelf sands that overlie a gravel lag which commonly rests on Pleistocene or Tertiary strata (Herb, 2000; Vanderburgh et al., 2010-this issue). The base of the Holocene deposit in the boreholes is at a depth comparable with the onshore projection of the marine transgressive unconformity seen in the seismic data (Vanderburgh et al., 2010-this issue).

The part of the shelf deposit within the study area outlined in Fig. 1 contains approximately $79 \mathrm{~km}^{3}$ of sediment. The shelf deposit appears 

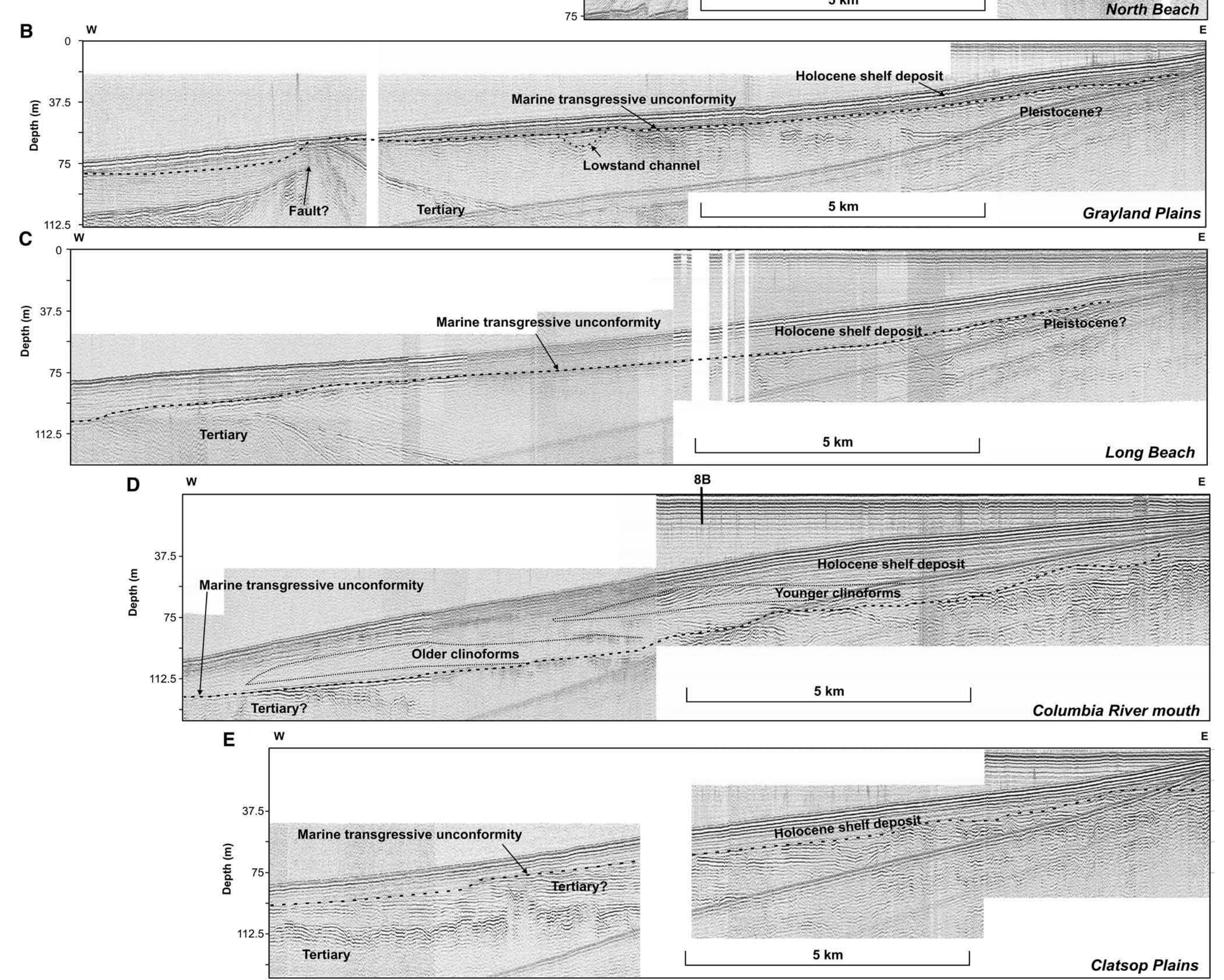

Fig. 3. S.eismic profiles (Uniboom) across the inner and middle shelf showing variations in the shelf stratigraphy along the length of the CRLC. (A) Folded Tertiary strata outcrop on the seafloor off North Beach, (B) a thin Holocene shelf deposit covers Tertiary and

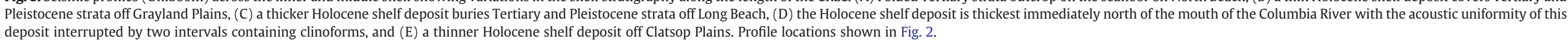



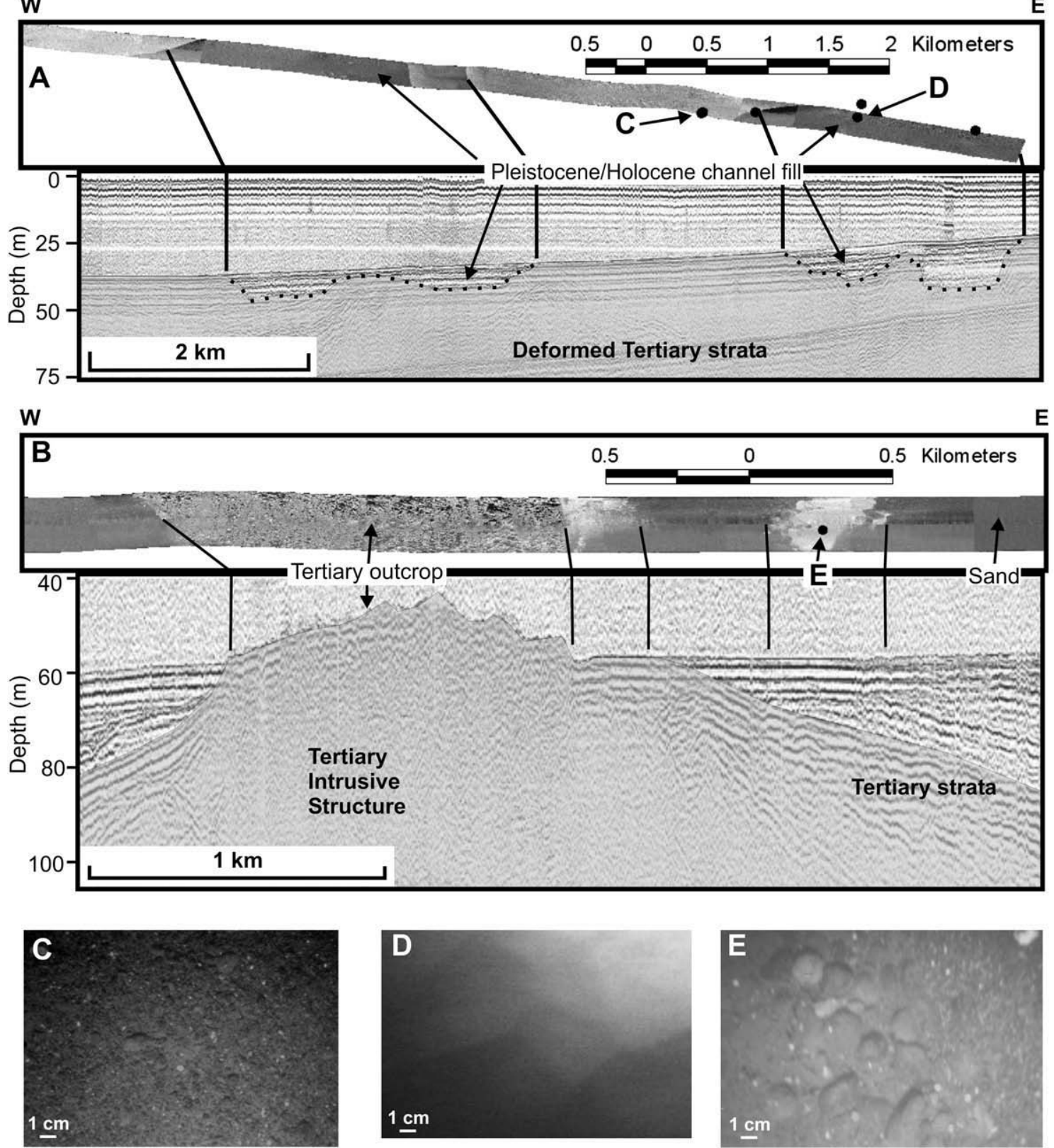

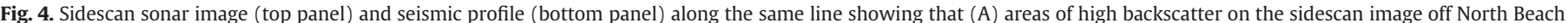

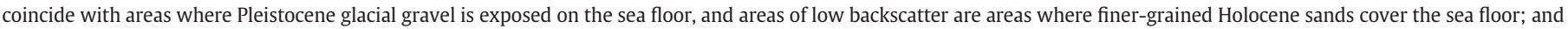

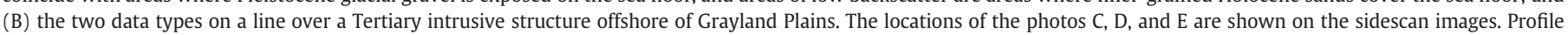
locations shown in Fig. 2.

to extend under some of the barrier beaches (Peterson et al., 2010-this issue), but its volume is small. The total volume of sediment that has accumulated above the marine transgressive surface, which includes both the shelf and barrier deposits, is $87 \mathrm{~km}^{3}$. Thus, the amount contained in the barriers and under the very innermost shelf (shoreward of the area outlined in Fig. 1) is only about $6 \mathrm{~km}^{3}$.

Although much of the shelf deposit is acoustically uniform, two intervals containing clinoforms interrupt the acoustically transparent nature of the deposit around the mouth of the Columbia River (Figs. 3D, 7C, 8B). The deeper of the two sets of clinoforms is as much as $18 \mathrm{~m}$ thick, $12 \mathrm{~km}$ wide, and extends northward from the paleoColumbia River approximately $21 \mathrm{~km}$ (Fig. 7A, C). The northern part of this clinoform unit rests directly on the marine transgressive unconformity, and the acoustically uniform shelf deposit underlies the southern part (Figs. 3D, 8A). The beds within this deposit dip offshore (Figs. 3D, 8A) except near its southern end where one profile shows an apparent southward dip (Fig. 8B). The tops of the clinoforms are truncated indicating some erosion subsequent to their formation (Fig. 8A). The depth where the shoreward side of this clinoform deposit pinches out against the marine transgressive unconformity is $65-70 \mathrm{~m}$. The second interval containing clinoforms forms an arcuate band around the mouth of the Columbia River (Fig. 7C). This deposit is less than $12 \mathrm{~m}$ thick, and its arcuate shape suggests it is an older ebb-tidal delta of the Columbia River that is broader in extent than the present delta. The top of this interval occurs in $42-55$ - $m$ water.

The remainder of the shelf deposit is acoustically uniform (Fig. 3B, $\mathrm{C}$, and E). Although high-resolution seismic profiles collected by Nittrouer (1978) on the outer shelf did show a shallow reflector that was interpreted to represent the base of the modern mid-shelf mud belt, this horizon was not identified on the profiles collected during this study. The reasons for its absence may be because it could not be 
resolved by the lower frequency seismic system used in this study, or that Nittrouer (1978) identified this reflector on profiles north of our study area in a part of this shelf deposit where the sediment is finer.

The surface sediment texture, like the Holocene sediment thickness, is not uniform across the study area. Instead, the deposit fines with increasing water depth except around inlet mouths (Fig. 5). Fine sand comprises more than $80 \%$ of samples in water depths less than $15 \mathrm{~m}, 30-40 \%$ in water depths of $20-35 \mathrm{~m}$, and less than $20 \%$ in most samples deeper that $40 \mathrm{~m}$ (Fig. 9). The very fine sand and silt plus clay fractions both show the inverse trend, being low near shore and increasing offshore. Medium sand and coarser material is less than $10 \%$ of all shelf samples within the bounds of the Holocene shelf deposit south of Grays Harbor, except for one sample on the innermost shelf off Long Beach and five samples off the mouth of the Columbia River. In the northern part of the study area, where the seismic data show Holocene sediment to be absent, the surface sediment is coarser. Medium sand and coarser material is found at all water depths off North Beach rather than being limited only to the innermost $20 \mathrm{~m}$ on the shelf as is the case south of Grays Harbor (Fig. 9).

The trend of offshore fining of surface sediment is interrupted off the mouth of the Columbia River. Here samples show that the surface

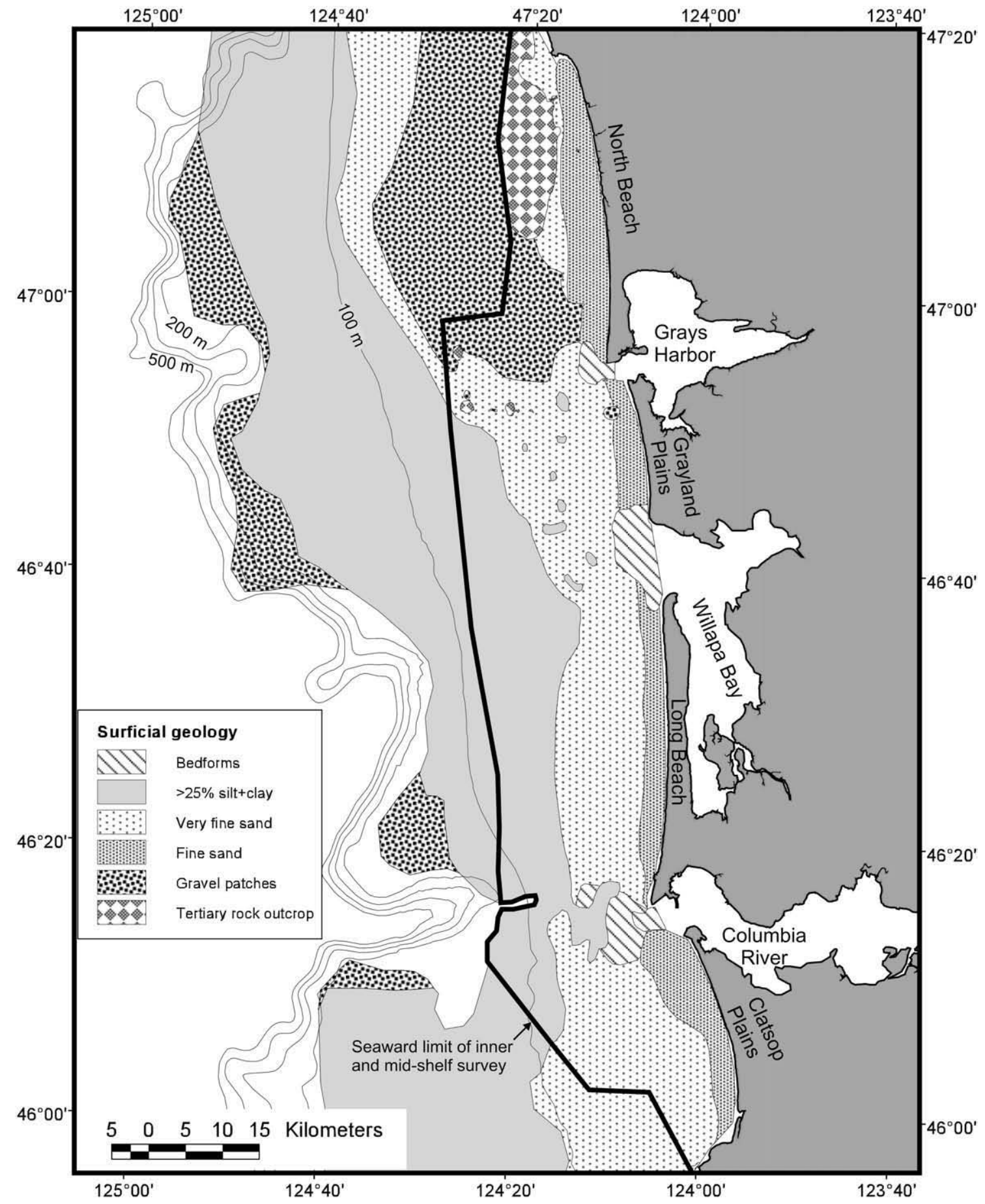

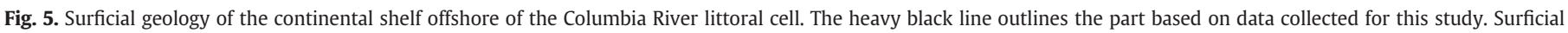
geology of the outer shelf is based on historical surface sediment samples (Roberts, 1974; Nittrouer, 1978). 

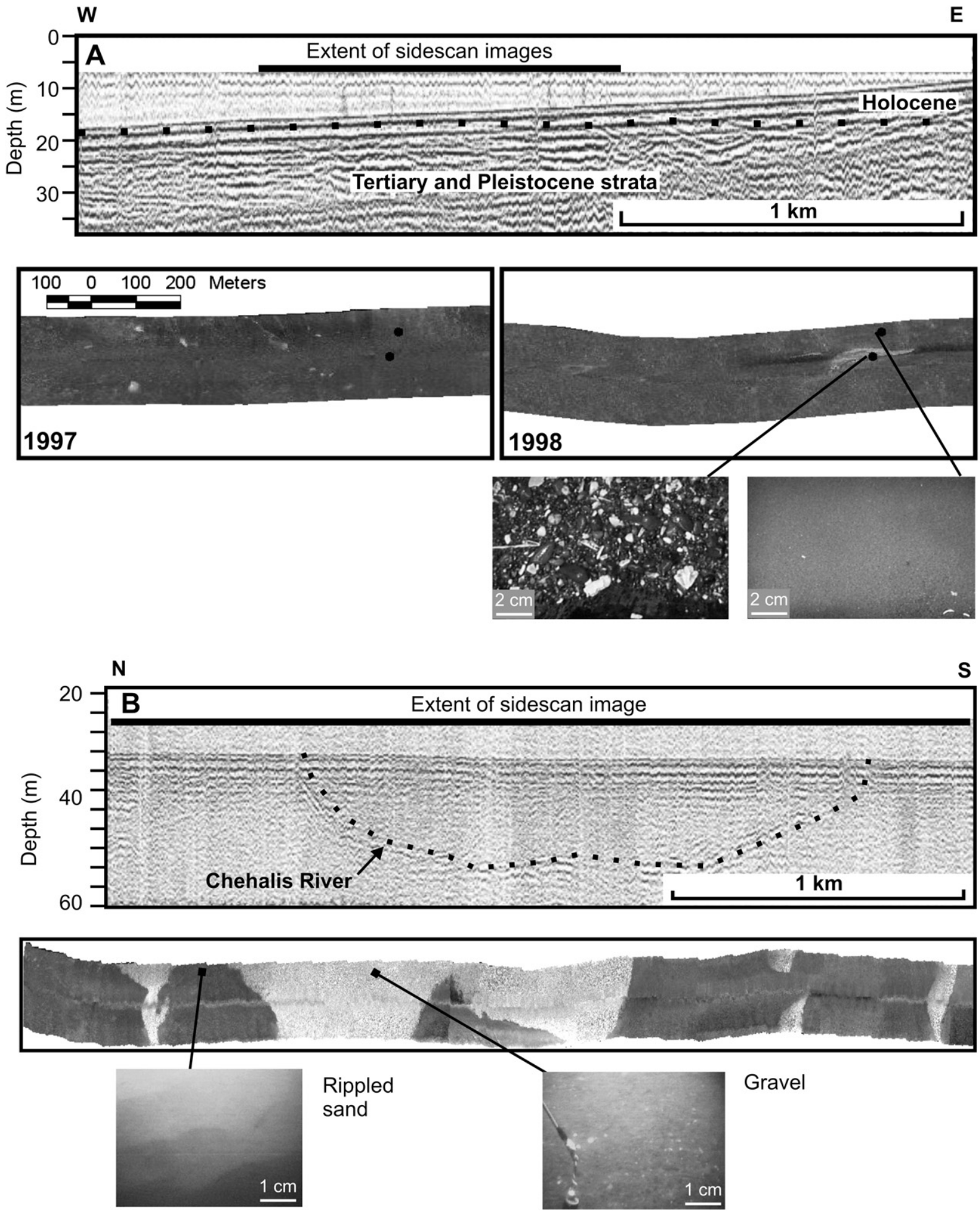

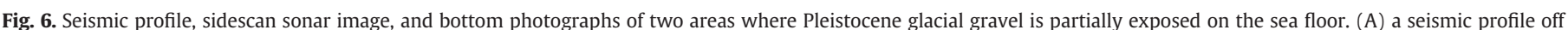

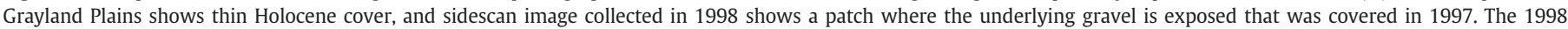

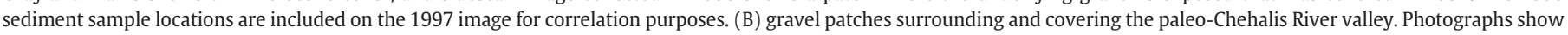
direct observations of the different sediment types. Profile locations shown in Fig. 2.

sediment is slightly coarser than to the north or south, and the sidescan imagery shows alternating bands of high and low backscatter radiating away from the inlet mouth. Megaripples are seen near the mouths of all three inlets, but the sediment off Willapa Bay and Grays Harbor was not found to be coarser than the surrounding shelf, and the sand ribbon-like features were not observed off the northern two inlets (Twichell et al., 2000).

\section{Discussion}

The barriers and beaches of the CRLC have accreted during the last $1000-5000$ years, and the growth of these beaches has been attributed to the large sediment contribution of the Columbia River during the latest Holocene (Woxell, 1998; Peterson et al., 1999, 2010this issue). In addition to supplying sediment to these actively 


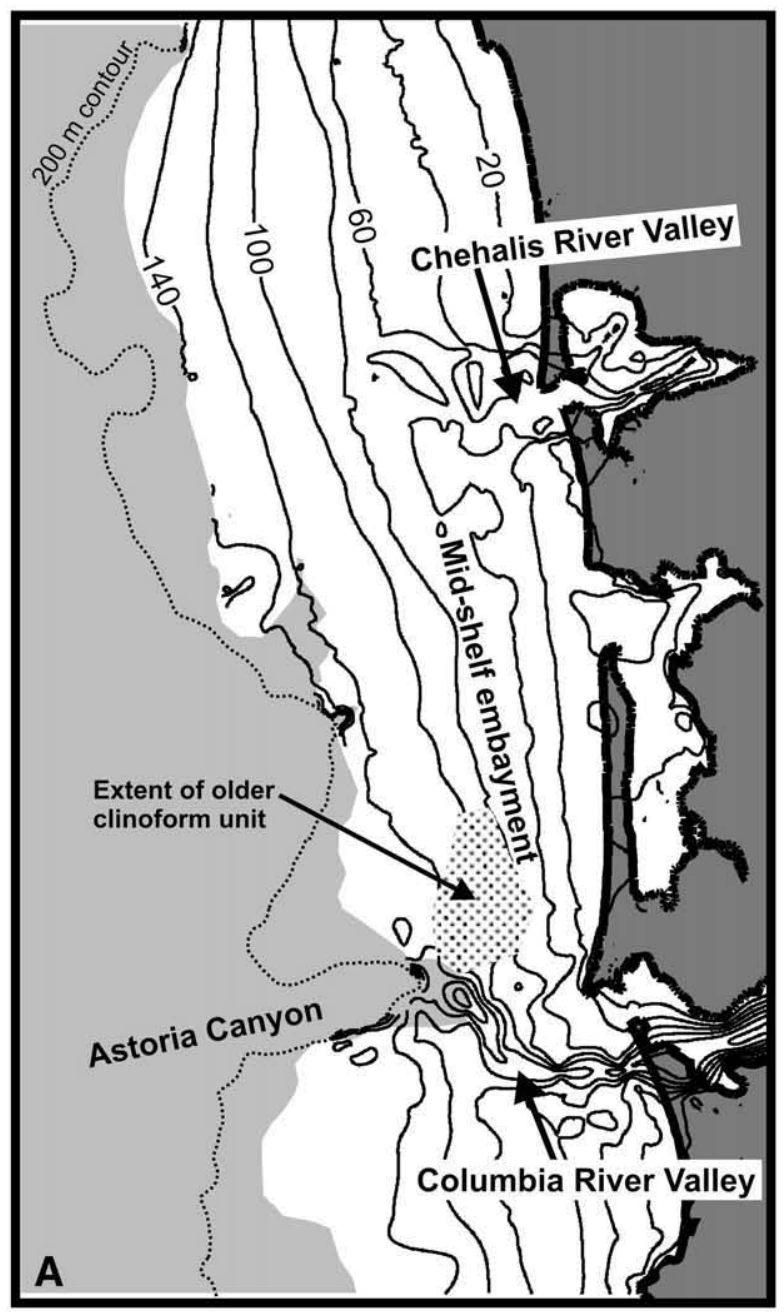

Depth to lowstand unconformity $(\mathrm{m})$

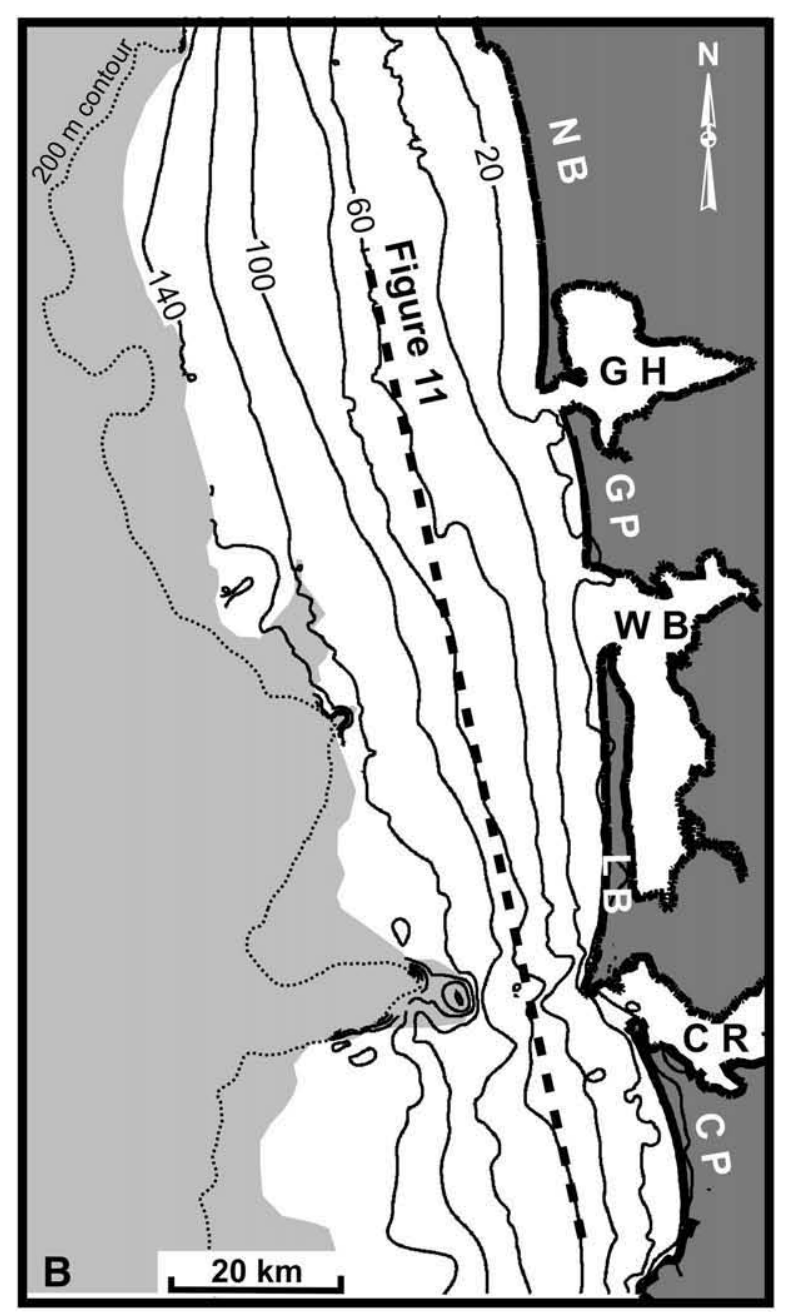

Depth to marine transgressive unconformity $(\mathrm{m})$

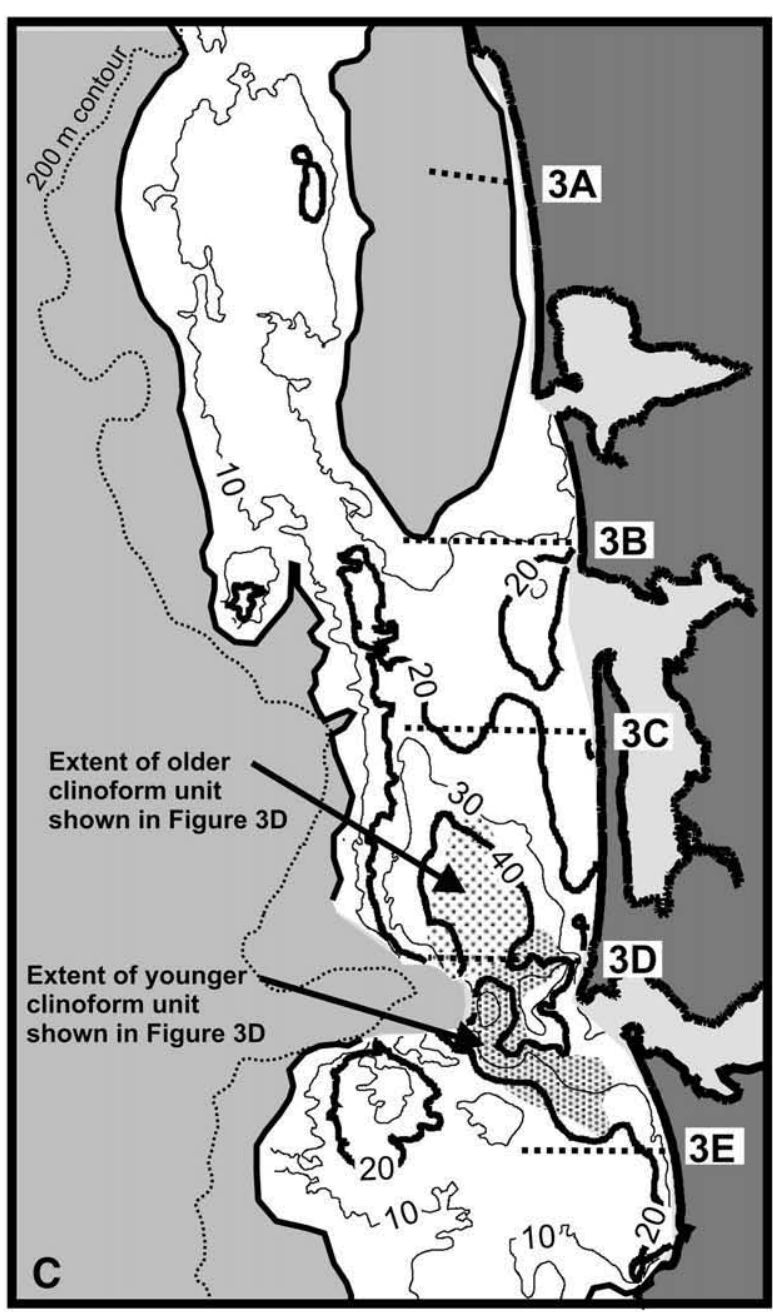

Holocene shelf sediment thickness (m)

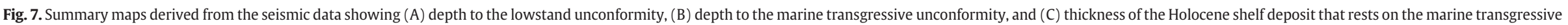

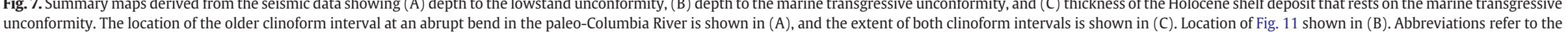
following locations: North Beach (NB), Grays Harbor (GH), Grayland Plains (GP), Willapa Bay (WB), Long Beach (LB), Columbia River (CR), and Clatsop Plains (CP). 

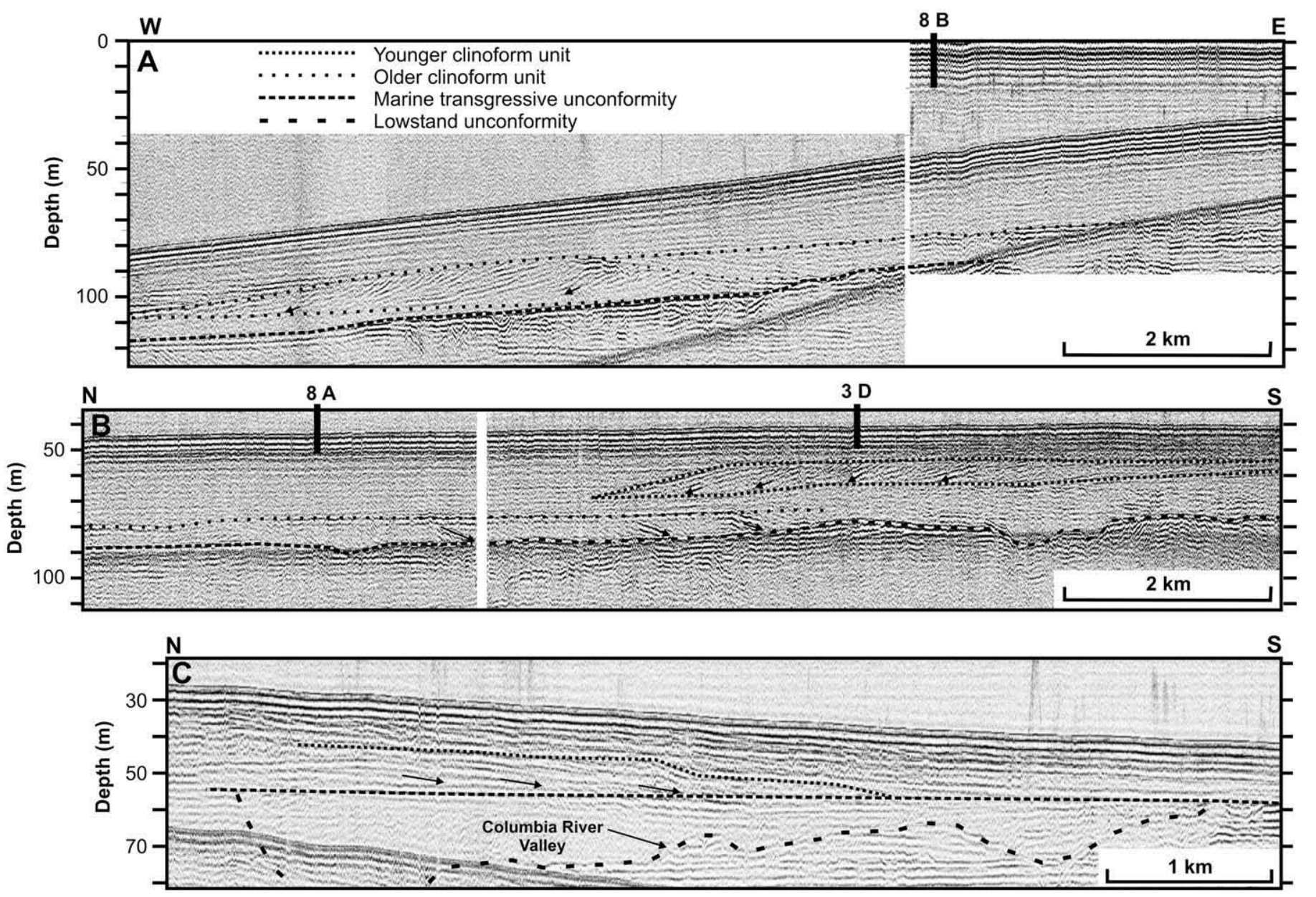

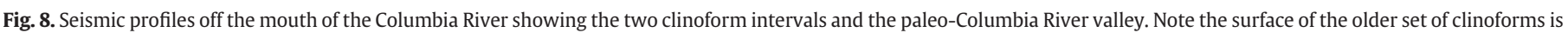

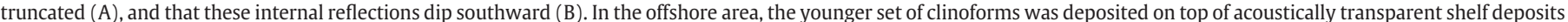
(B) while farther shoreward and to the south it rests directly on the marine transgressive surface (C). Profile locations shown in Fig. 2.

accreting barriers, the river also supplied a huge volume of sediment to the adjacent continental shelf (Figs. 7C, 10). It has been unclear whether beach accretion took place by along-shore transport of Columbia River input or by onshore transport from the shelf (Peterson et al., 2010-this issue). Here, we discuss the effect of pre-existing stratigraphy and the long-term response of the shelf to the processes recorded in the present surface and shallow subsurface sediments of the inner and middle shelf off the CRLC. The discussion will focus on four points: (1) the stratigraphy of the Holocene deposits suggest sediment accumulation on the shelf has not been constant through the Holocene, (2) Holocene sediments are not uniformly distributed along the length of the CRLC, (3) the modern shelf deposit continues to be actively reworked by modern processes, and (4) much of the shelf surface is finer-grained than the adjacent beaches and therefore would appear to be a sink to, or only a minor source of beach sand.

A variety of terms are in use that describe the transition between the beach and the shelf, and for clarification we define our terminology here. The shoreward extent of the study area is on the lower shoreface, and the study area extends across the inner shelf to the middle and outer shelf, which we lump together. We base the transitions between these three zones on facies changes. The boundaries are gradational, and we have arbitrarily defined them such that the lower shoreface coincides with areas having mean grain size of surface samples coarser than fine sand $(125 \mu \mathrm{m})$. The inner shelf occupies the area where the mean grain size is finer than $125 \mu \mathrm{m}$ but the mud content is less than $25 \%$. The middle and outer shelf is where the mud content exceeds 25\%. By these definitions, the transition from lower shoreface to shelf normally is in $15-25 \mathrm{~m}$ water depths, and the transition from inner to middle shelf is in approximately 55-m water depth.

\subsection{Evidence for varied sedimentation rates through the Holocene}

The seismic-reflection profiles show that the Holocene deposit on the shelf can be broken into two parts, which are separated by the marine transgressive unconformity (Fig. 11). Below this unconformity are fluvial and bay sediment filling the paleo-river valleys of the Columbia and Chehalis Rivers (Peterson and Phipps, 1992; Baker et al., 2010-this issue). The Columbia River is the deeper of the two valleys and sediment started accumulating at the borehole site about $16,000 \mathrm{yr}$ BP (Baker et al., 2010-this issue). Boreholes into the Chehalis and Columbia River valleys recovered only fluvial and shallow estuarine deposits, which indicate that sedimentation in these valleys kept pace with the Holocene rise in sea level, even during the early Holocene when sea level rose rapidly (Peterson and Phipps, 1992; Baker et al., 2010-this issue).

Within the modern shelf deposit, which overlies the marine transgressive unconformity, sediment accumulation rates decreased through time. Nittrouer (1978) estimated average sedimentation rates of $1-2 \mathrm{~m} / 1000$ years based on ${ }^{210} \mathrm{~Pb}$ measurements. ${ }^{14} \mathrm{C}$ dates from vibracores suggest that recent sediment accumulation rates are only $10-70 \mathrm{~cm} / 1000$ years (Kaminsky and Ferland, 2003). In both cases, the amount of sediment on the shelf at the sample sites exceeds 

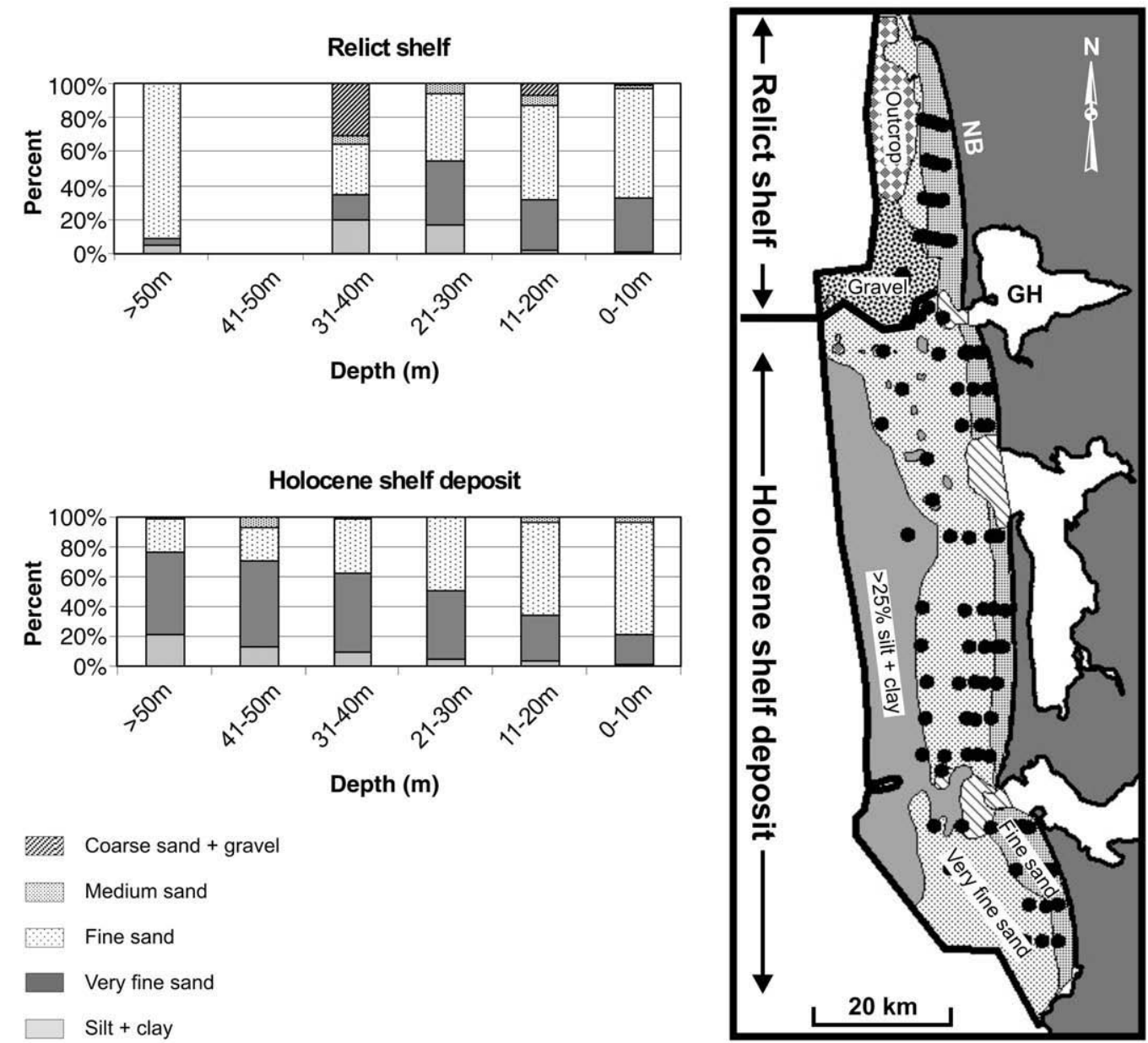

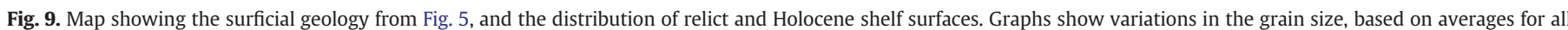
samples within each depth interval, for both the modern and relict parts of the shelf. Map abbreviations refer to North Beach (NB) and Grays Harbor (GH).

what would have been deposited if these were average accumulation rates throughout the Holocene.

Much of the shelf deposit is acoustically uniform, but the two intervals containing clinoforms off the mouth of the Columbia River suggest pulses of rapid sediment input during the early phase of deposition. The older interval of clinoforms, whose top is as shallow as $65-70 \mathrm{~m}$, occupies part of an embayment on the middle shelf north of a point where the paleo-Columbia River makes abrupt turns first to the north and then back to the west (Fig. 7A). The regional sea level curve compiled by Peterson and Phipps (1992) and modified by Baker et al. (2010-this issue) shows that the sea level was $70 \mathrm{~m}$ lower than the present 11,500 years BP. This age coincides with the final stages of the Missoula floods in the Columbia River Basin (Mullineaux et al., 1978; Waitt, 1985), and the deeper clinoforms may have been deposited during these floods. Baker et al. (2010-this issue) attribute the lower $45 \mathrm{~m}$ of the borehole drilled at the mouth of the Columbia River to deposition from these floods. Drilling in the Escanaba Trough, $800 \mathrm{~km}$ from the present mouth of the Columbia River recovered Missoula flood deposits as well (Brunner et al., 1999). Thus we suggest that the deeper clinoform unit is the shelf record of these floods. The origin of this deposit could be similar to sediment lobes on the outer shelf off the Hudson River that are attributed to the catastrophic drainage of glacial lakes (Uchupi et al., 2001). Alternatively, it could represent a barrier beach similar to those preserved on the Australian shelf that resulted from reworking of flood deposits by coastal processes (Roy et al., 1994).

The arcuate shape of the shallower interval of clinoforms suggests it is an ebb-tidal delta. The top of this deposit is in about $50 \mathrm{~m}$ of water and may be associated with the period of greatest sediment accumulation at the Warrenton site 9000 BP (Baker et al., 2010-this issue). Regardless of the origin of these clinoforms, their formation when sea level was rising rapidly suggests periods of rapid sediment input. The eroded surface of the deeper of these deposits suggests sediment input diminished abruptly allowing erosion by marine processes to have removed part of its surface (Fig. 8A).

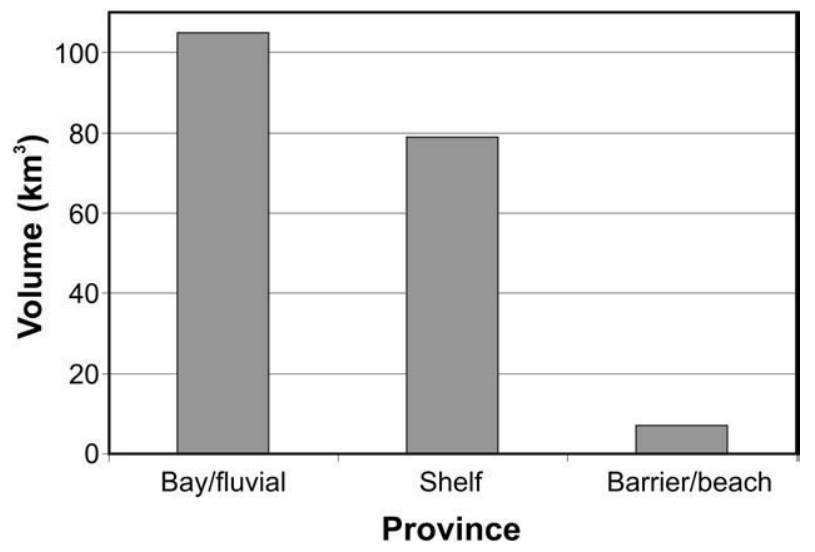

Fig. 10. The volume of sediment contained in each of the three provinces. The volume of fluvial and bay deposits is the sum of Columbia River fill reported by Baker et al. (2010this issue) and the amount in other bays and underlying the shelf (Twichell and Cross, 2001). 
The time lines in the modern shelf deposit on Fig. 11 draw on the inferred ages of the clinoforms as well as age dates from vibracores collected by Kaminsky and Ferland (2003) and Phillips and Dunhill (1999). Sedimentation rates during the last 4000 years are lower than earlier in the Holocene (Kaminsky and Ferland, 2003). Continued high sedimentation rates on the middle shelf are limited to the area off the mouth of the Columbia River (Fig. 11). Although the Missoula floods were spectacular, the volume deposited on the shelf was modest in comparison to the total shelf volume. At this time large volumes of sediment bypassed the shelf and were deposited in the deep sea (Brunner et al., 1999) probably due to limited accommodation space on the shelf. Prior to $4000 \mathrm{yr}$ BP, shelf sedimentation appears to have been highest during the middle part of the Holocene; whether it is tied to the period of increased sediment accumulation rates in the lower Columbia River estuary or a period of increased sediment bypass through the lower estuary (Baker et al., 2010-this issue) will await a drill hole on the shelf.

\subsection{Varied Holocene sediment distribution on the shelf-structural control and sediment supply}

The surficial geology of the shelf varies along the length of the CRLC. North of Grays Harbor much of the inner and middle shelf is a relict surface where Tertiary and Pleistocene strata are still exposed on the sea floor (Fig. 9). Off Grayland Plains, the modern shelf deposit is thin and patchy (Figs. 5, 7C), and then abruptly thickens south of the mouth of Willapa Bay (Fig. 11). Boreholes show that the barriers shoreward of the relict shelf are only 1-11 m thick while those shoreward of the modern shelf deposit are 20-36 m thick (Herb, 2000; Vanderburgh et al., 2010-this issue).

The distribution and thickness of the shelf deposit is partially controlled by the original geometry of the surface upon which it was deposited. Figs. 7B and 11 show that the surface underlying the shelf deposit shoals abruptly just north of the entrance to Willapa Bay. The abrupt shoaling may mark the offshore transition between two crustal blocks that have been identified on land (McCrory, 1996; McCrory et al., 2002), and would indicate that antecedent structures partially control the location of the depocenter for the Holocene shelf deposit. South of the mouth of Willapa Bay there was more accommodation space to be filled, particularly on the middle shelf, before deposition on the shelf could spread farther north.

Although the accommodation space determined by earlier structures on the shelf partially explains the location of the Holocene depocenter, the thickest part of the deposit is off the mouth of the Columbia River (Fig. 7C). The increased thickness here is not due to a depression in the original surface, but instead is due to a mounding of the deposit at this location (Fig. 11). The mounding of the surface of the deposit indicates that sediment dispersal processes from the Columbia River source also control its geometry.

\subsection{Modern processes actively rework shelf surface sediment at all depths}

The surface of much of the modern shelf deposit is uniform and featureless on the sidescan sonar images (Twichell et al., 2000); yet other evidence indicates that much of shelf's surface continues to be actively reworked by modern marine processes. Certainly, results from the STRATAFORM program on the Eel River shelf indicate active reworking of a similar modern shelf deposit (Cacchione et al., 1999; Ogston and Sternberg, 1999). The presence of ripples in 55-m water depth in the summer (Twichell et al., 2000), documentation of ripples at all depths on the Oregon shelf during the winter (Komar et al., 1972), and measurable bathymetric changes between surveys in the 1920s and 1990s (Buijsman et al., 2003) all support the continued reworking of this shelf surface. Off Grayland Plains, where the Holocene shelf deposit is thin, there is further evidence of ongoing reworking of the shelf deposit. Here, a patch of gravel was exposed between the two sidescan surveys conducted in 1997 and 1998 (Fig. 6A). The origin of this linear gravel patch appears similar to rippled-scour depressions observed on other shelves (Cacchione et al., 1984; Schwab et al., 1997). Similar depressions may have formed farther south where the shelf deposit is thick, but because of the lack of textural variability they

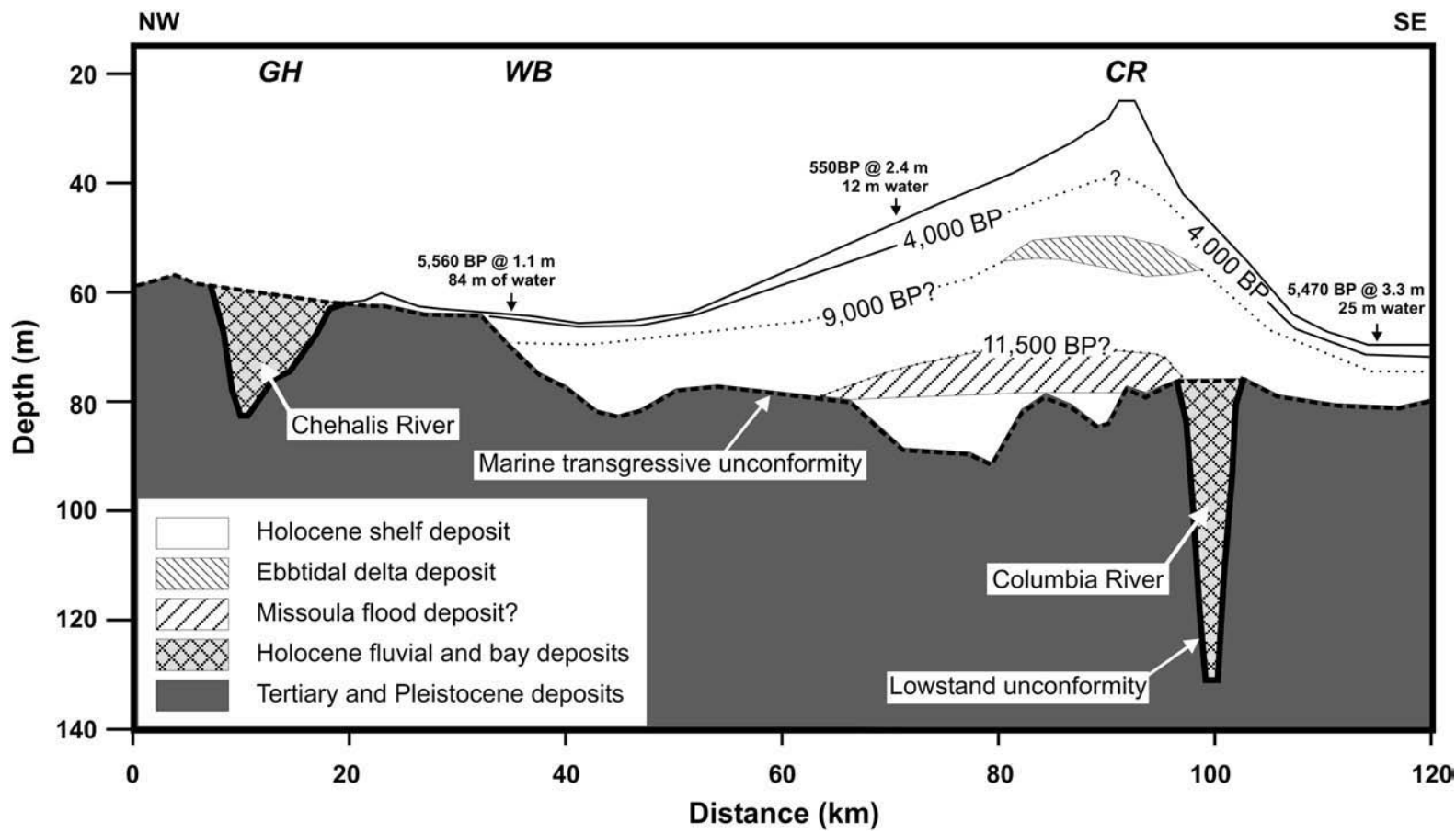

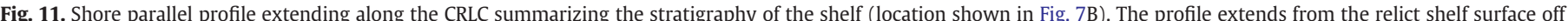

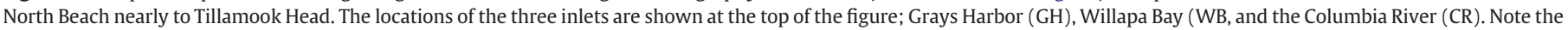
abrupt shoaling of the pre-Holocene strata north of the mouth of Willapa Bay. Time lines are inferred from results summarized in the text. 
were not apparent. Because these depressions are preserved only where the Holocene cover is less than 1-2 m thick, variable sediment types appear to be necessary for the formation or preservation of these features. These gravel floored depressions may be a valuable marker of relict shelf surfaces in other modern shelf environments as well as in the stratigraphic record.

\subsection{Offshore fining of surface sediment is inconsistent with present shelf being a source for beach sand}

The redistribution of the Holocene shelf deposit is dynamic and ongoing, but the long-term result has been a net offshore fining of the surface sediment (Fig. 9). Whether the inner shelf is a source or sink for beach sediment had been unclear; however the fine-grained nature of inner shelf samples suggests that this area is not a major source of beach sand. Sediment samples collected on the beach show the median grain size to be $125-225 \mu \mathrm{m}$ along the entire length of this littoral cell except for some gravel on the beaches of Grayland Plains and North Beach (Ruggiero et al., 1999; Ruggiero and Voigt, 2000). By contrast, the median grain size of shelf sediment in water less than $10 \mathrm{~m}$ ranges from 177 to $210 \mu \mathrm{m}$, while samples in water depths greater than $25 \mathrm{~m}$ all are finer than $125 \mu \mathrm{m}$ (Twichell et al., 2000). Fig. 9 shows changes in partitioning of sediment by size ranges across the shelf. The fraction of sediment that is fine sand and coarser material (coarser than $125 \mu \mathrm{m}$ ) comprises most of the beach material (Ruggiero and Voigt, 2000). This size range comprises $79 \%$ of samples collected from water depths less than $10 \mathrm{~m}$. This coarse fraction decreases to $45 \%$ in water depths of $21-30 \mathrm{~m}$ and is only $22 \%$ of samples in 51-60 m depths. If the shelf were a major source of sediment for the beaches, a substantial volume of very fine sand and mud would have to be winnowed from the shelf to provide sediment of the proper composition to the beaches.

\section{Summary}

A huge volume of Holocene-age sediment is stored on the shelf compared to the barriers (Fig. 10). The evolution of the shelf deposit suggests slow accumulation during the early Holocene due to limited accommodation space, rapid accumulation during the middle Holocene and slower accumulation during the latest Holocene (Fig. 11). This speculation is supported both by the drill hole at the mouth of the Columbia River (Baker et al., 2010-this issue) and vibracores collected on the shelf (Kaminsky and Ferland, 2003). The shelf stratigraphy suggests large volumes of sediment were introduced to the system during very short events. Modern processes actively rework the present shelf surface, and surface sediment becomes progressively finer offshore. Only the lower shoreface is texturally similar to the subaerial beach, so only a small part of this large shelf deposit could serve as a supply of sand for the beaches.

\section{Acknowledgments}

Credit for the success of this field program is largely due to Kenneth Parolski who put in long hours under less than ideal conditions keeping aging, temperamental equipment running and scientists in good humor. We also acknowledge Daniel O'Hagan and George Maddox, the two captains of the Washington State Department of Fish and Wildlife vessel CORLISS, for their willingness to help and skill as boat operators. George Kaminsky and Guy Gelfenbaum oversaw many of the administrative aspects of this project, and also provided many valuable scientific insights. We appreciate the many lively and rewarding discussions with James Phipps, Loraine Woxell, Sandy Vanderburgh, David Percy, April Herb, Harry Jol, and Diana Baker that greatly enriched the final product. The manuscript has benefited from reviews by Jeff Williams, David Stolper, Donald Swift, and Terry Bruns.

\section{References}

Baker, D., Peterson, C., Hemphill-Haley, E., Twichell, D., 2010. Latest-Pleistocene and Holocene (2-16 ka) sedimentation in the Columbia River Estuary, Oregon, USA Marine Geology 273, 83-95 (this issue).

Ballard, R.L., 1964. Distribution of beach sediment near the Columbia River. University of Washington, Department of Oceanography, Tech. Rept. No. 98. 82 pp.

Blackwood, D.B., Parolski, K.F., 2001. Seabed observation and sampling system. Sea Technology 39, 40-43.

Brunner, C.A., Normark, W.R., Zuffa, G.G., Serre, F., 1999. Deep-sea sedimentary record of the late Wisconsin cataclysmic floods from the Columbia River. Geology 27, 463-466.

Buijsman, M.C., Sherwood, C.R., Gibbs, A.E., Gelfenbaum, G., Kaminsky, G., Ruggiero, P., Franklin, J., 2003. Regional sediment budget of the Columbia River littoral cell, USA. U.S. Geol. Surv. Open-File Rept. 02-281. 137 pp.

Cacchione, D.A., Drake, D.D., Grant, W.D., Tate, G.B., 1984. Rippled scour depressions on the inner continental shelf off Central California. Journal of Sedimentary Petrology $54,1280-1291$

Cacchione, D.A., Wiberg, P.L., Lynch, J., Irish, J., Traykovski, P., 1999. Estimates of suspended-sediment flux and bedform activity on the inner portion of the Eel continental shelf. Marine Geology 154, 83097.

Cross, V., Twichell, D., Parolski, K., Harrison, S., 1999a. Archive of boomer seismicreflection data collected aboard RV CORLISS cuisse CRLS97007 off northern Oregon and southern Washington inner continental shelf. U.S. Geol. Surv. Open-File Rept. 98-351, 2 CDROMs.

Cross, V., Twichell, D., Parolski, K., 1999b. Archive of seismic-reflection data collected aboard RV CORLISS cruise CRLS98014 in the Columbia River Estuary, Willapa Bay, and off southern Washington inner continental shelf. U.S. Geol. Surv. Open-File Rept. 99-307, 3 CDROMs.

Curray, J.R., 1965. Late Quaternary history, continental shelves of the United States. In: Wright, H.E., Frey, D.G. (Eds.), The Quaternary of the United States. Princeton Univ. Press, Princeton, NJ, pp. 723-735.

Emery, K.O., 1968. Relict sediments on continental shelves of the world. American Association of Petroleum Geologists Bulletin 52, 445-464.

Flood, R.D., Ferrini, V.L., Giosan, L., Zaleski, L., 1999. Preliminary results of a multibeam bathymetry and backscatter survey. In: Gelfenbaum, G., Kaminsky, G.M. (Eds.), Shouthwest Washington Coastal Erosion Workshop Report 1999, U.S. Geol. Surv. Open-File Rept. 00-439, pp. 81-83.

Gelfenbaum, G., Roelvink, J.A., Meijs, M., Buijsman, M., Ruggiero, P., 2003. Process based morphological modeling of Grays Harbor inlet at decadal timescales. Proceedings of Coastal Sediments '03. ASCE. 13 pp.

Gross, G.M., McManus, D.A., Ling, H., 1967. Continental shelf sediment, northwestern United States. Journal of Sedimentary Petrology 37, 790-795.

Herb, A.A., 2000, Holocene stratigraphy and sediment volumes for the Columbia River littoral cell, Pacific Northwest, USA: MS thesis, Portland State Univ., Portland, OR, $127 \mathrm{p}$.

Kaminsky, G.M., Ferland, M.A., 2003. Assessing the connections between the inner shelf and the evolution of Pacific northwest barriers through vibracoring. Proceedings of Coastal Sediments '03. ASCE. 12 pp.

Komar, P.D., Neudeck, R.H., Kulm, L.D., 1972. Observations and significance of deepwater oscillatory ripple marks on the Oregon continental shelf. In: Swift, D.J.P., Duane, D.B., Pilkey, O.H. (Eds.), Shelf Sediment Transport: Process and Pattern. Dowden, Hutchinson, and Ross, Stroudsburg, PA, pp. 601-619.

Krumbein, W.C., 1934. Size frequency distributions of sediments. Journal of Sedimentary Petrology 4, 65-77.

McCrory, P.A., 1996. Tectonic model explaining divergent contraction directions along the Cascadia subduction margin, Washington. Geology 24, 929-932.

McCrory, P.A., Foster, D.S., Danforth, W.W., Hamer, M.R., 2002. Crustal deformation at the leading edge of the Oregon coast range block, offshore Washington (Columbia River to Hoh River). U.S. Geol. Surv. Prof. Paper 1661-A. 47 pp.

Mullineaux, D.R., Wilcox, R.E., Ebauch, W.F., Fryxel, R., Rubin, M., 1978. Age of the last major scabland flood of the Columbia Plateau in eastern Washington. Quaternary Research 10, 171-180.

Nittrouer, C. A., 1978, The process of detrital sediment accumulation in a continental shelf environment: an examination of the Washington shelf: Thesis, University of Washington, Seattle, WA, 243 pp.

Ogston, A.S., Sternberg, R.W., 1999. Sediment-transport events on the northern California continental shelf. Marine Geology 154, 69-82.

Peterson, C.D., Phipps, J.B., 1992. Holocene sedimentary framework of Grays Harbor Basin, Washington, USA. In: Fletcher, C.H., Wehmiller, J.F. (Eds.), Marine and Lacustrine Systems, SEPM Spec. Publ. No. 48, pp. 273-285.

Peterson, C.D., Gelfenbaum, G.R., Jol, H.M., Phipps, J.B., Reckendorf, F., Twichell, D.C. Vanderburg, S., Woxell, L., 1999. Great earthquakes, abundant sand, and high wave energy in the Columbia cell, USA. Proceedings of Coastal Sediments '99: ASCE, vol. 2, pp. 1676-1691.

Peterson, C.D., Vanderburg, S., Roberts, M.C., Jol, H.M., Phipps, J., Twichell, D.C., 2010. Composition, age and depositional rates of shoreface deposits under barriers and beach plains of the Columbia River littoral cell, USA. Marine Geology 273, 62-82 (this issue).

Phillips, R.L., Dunhill, G., 1999. Sedimentation rates and occurrences of tephra in cores from the southwest Washington shelf. In: Gelfenbaum, G., Kaminsky, G.M. (Eds.) Shouthwest Washington Coastal Erosion Workshop Report 1999, U.S. Geol. Surv. Open-File Rept. 00-439, pp. 27-30.

Poppe, L.J., Eliason, A.H., Fredericks, J.J., 1985. APSAS; An Automated Particle Size Analysis System. U.S. Geological Survey Circular 96377 pp.

Roberts, R.W., 1974. Marine sedimentological data of the Washington continental shelf. University of Washington, Dept. Oceanogr. Spec. Rept. 57. 129 pp. 
Roy, P.S., Cowell, P.J., Ferland, M.A., Thom, B.G., 1994. Wave-dominated coasts. In: Carter, R.W.G., Woodroffe, C.D. (Eds.), Coastal evolution: Late Quaternary shoreline morphodynamics. Cambridge University Press, pp. 121-186.

Ruggiero, P., Voigt, B., 2000. Beach monitoring in the Columbia River littoral cell, 19972000. Publication No. 00-06-26, Coastal Monitoring and Analysis Program. Washington Department of Ecology, Olympia, WA. 112 pp.

Ruggiero, P., Cote, J., Kaminsky, G.M., Gelfenbaum, G., 1999. Scales of variability along the Columbia River littoral cell. Proceedings of Coastal Sediments '99: ASCE, vol. 2 pp. 1692-1707.

Schwab, W.C., Allison, M.A., Corso, W., Lotto, L.L., Butman, B., Buchholtz ten Brink, M. Denny, J.F., Danforth, W.W., Foster, D.S., 1997. Initial results of high-resolution seafloor mapping offshore of the New York-New Jersey metropolitan area using sidescan sonar. Northeastern Geology and Environmental Sciences 19, 243-262.

Shideler, G.L., 1976. A comparison of electronic particle counting and pipette techniques in routine mud analysis. Journal of Sedimentary Petrology 46, 1017-1025.

Smith, J.M., Messmer, L.W., Phipps, J.B., Samuelson, D.F., Schermer, E.D., 1980. Grays Harbor and Chehalis River improvements to navigation environmental studies Grays Harbor ocean disposal study: literature review and preliminary benthic sampling. U. S. Army Corps of Engineers Internal Rept. 28 pp.

Sternberg, R.W., 1986. Transport and accumulation of river-derived sediment on the Washington continental shelf, USA. Journal of the Geological Society of London 143 945-956.

Swift, D.J.P., 1970. Quaternary shelves and the return to grade. Marine Geology 8, 5-30.

Twichell, D.C., Cross, V.A., 2001. Holocene evolution of the southern Washington and northern Oregon shelf and coast: geologic discussion and GIS data release. U.S. Geol.I Surv. Open-File Rept. 01-076. 28 pp.
Twichell, D.C., Cross, V.A., Parolski, K.F., 2000. Sidescan-sonar imagery, surface sediment samples, and surficial geologic interpretation of the southwestern Washington inner continental shelf based on data collected during CORLISS cruises 97007 and 98014. U.S. Geol. Surv. Open-File Rept. 00-167. 29 pp.

Uchupi, E., Driscoll, N., Ballard, R.D., Bolmer, S.T., 2001. Drainage of late Wisconsin glacial lakes and the morphology and late Quaternary stratigraphy of the New Jersey-southern New England continental shelf and slope. Marine Geology 172, 117-145.

Vanderburgh, S., Roberts, M.C., Peterson, C.D., Phipps, J.B., Herb, A., 2010. Transgressive and regressive deposits forming the barriers and beachplains of the Columbia River Littoral Cell, USA. Marine Geology 273, 32-43 (this issue).

Venkatarathnam, K., McManus, D.A., 1973. Origin and distribution of sands and gravels on the northern continental shelf off Washington. Journal of Sedimentary Petrology 43, 799-811.

Waitt, R.B., 1985. Case for periodic, colossal jokulhlaups from Pleistocene glacial Lake Missoula. Bulletin of the Geological Society of America 96, 1271-1286.

Walker, G.W., and McLeod, N.S., 1991, Geologic map of Oregon: U.S. Geol. Surv., scale $1: 500,000,2$ sheets.

Wentworth, C.K., 1929. Method of computing mechanical composition types in sediments. Bulletin of the Geological Society of America 40, 771-790.

Wolf, S.C., Hamer, M.R., and McCrory, P.A., 1997, Quaternary geologic investigations of the continental shelf offshore southern Washington and northern Oregon: U.S. Geol. Surv. Open-File Rept. 97-677, scale 1:500,000, 4 plates.

Woxell, L.K., 1998, Prehistoric beach accretion rates and long-term response to sediment depletion in the Columbia River littoral system, USA: MS thesis, Portland State Univ., Portland, OR, 206 p. 